\title{
Abbreviations
}

\section{SAMUEL BECKETT}

The Collected Works of Samuel Beckett. New York: Grove, 1970.

Cas $\quad$ Cascando and Other Short Dramatic Pieces

HD Happy Days

HII How It Is

K Krapp's Last Tape and Other Dramatic Pieces

MD Malone Dies

MO Molloy

MPTK More Pricks Than Kicks

MU Murphy

PR Proust

STFN Stories and Texts for Nothing

UN The Unnamable

W Watt

WG Waiting for Godot

The following Beckett texts are not part of the 1970 Collected Works; Grove Press editions, however, have been used for citations.

C Company, 1980

Disjecta Disjecta, 1984

ISIS IIl Seen Ill Said, 1981

LO The Lost Ones, 1972

TN Three Novels: Molloy, Malone Dies, The Unnamable, 1955 


\section{JAMES JOYCE}

$\mathrm{D}$

FW

$\mathrm{P}$

$\mathrm{SH}$

U
Dubliners. Ed. Robert Scholes. New York: Viking, 1957.

Finnegans Wake. New York: Viking, 1939.

A Portrait of the Artist as a Young Man. Ed. Richard Ellmann. New York: Viking, 1964.

Stephen Hero. Ed. John J. Slocum and Herbert Cahoon. New York: New Directions, 1963.

Ulysses. Ed. Hans Walter Gabler et al. 3 vols. New York: Garland, 1984. 